\title{
Impacts of Entrepreneurial Motivation on Entrepreneurship Intention
}

\author{
Muhammad Iffan \\ Departement of Management \\ Universitas Komputer Indonesia \\ Bandung, Indonesia \\ m.iffan@email.unikom.ac.id
}

\begin{abstract}
This research aimed at determining the impact of entrepreneurial motivation on entrepreneurship intention. Method used in this research was quantitative analysis using path analysis with validity and reliability test. Sampling method used in this research is random sampling through the distribution of a series of questionnaires to 172 students at a private university as a case study. This research investigated perceived behavioral control and subjective norm as dimensions in an entrepreneurial motivation variable that affected immediate term entrepreneurship intention. The result showed that both factors have significant effect on immediate term entrepreneurship intention either partially or simultaneously. Entrepreneurial motivation of students could be a main factor that increased entrepreneurship intention. The finding of the research contributes to encourage students to start and own a business.
\end{abstract}

Keywords - Entrepreneurial Motivation, Entrepreneurship Intention, Perceived Behavioral Control, Subjective Norm, Immediate Term Intention

\section{INTRODUCTION}

Nowadays entrepreneurship has become more crucial and become mainstream business disciplines in the competitive digital world $[1,2]$. Entrepreneurial motivation and entrepreneurship intention are the main determining success factor in entrepreneurship success. Additionally, Entrepreneurial motivation play a significant role toward entrepreneurship intention [3]. Motivation has a great value because it makes people to act [4]. Meanwhile Entrepreneurial intention is defined as a person's desire to start a new business or create new business value [5]. Entrepreneurial motivation is covering attitude toward the behavior, subjective norm and perceived behavioral control [6]. Entrepreneurship intention is covering immediate term intention and future intention [7]. Therefore, the research to find the relations between listed variables is become interested to be performed. The research is was conducted by measuring variables such as perceived behavioral control and subjective norm of entrepreneurial motivation, and also immediate term entrepreneurship intention.

There were prior researches showed the relations between entrepreneurial motivation and entrepreneurship intention. Entrepreneurship intention among Malay University Students indicated that perceived behavioral control and subjective norm have a significant influence on student's intention. However, the research in not explained yet about the immediate term intention specifically [8]. Another previous research indicated that entrepreneurial motivation has significant effects to student immediate entrepreneurship intention. Unfortunately; the research did not describe about the relationship between perceived behavioral control and subjective norm [7]. The prior studies showed that entrepreneurial motivation has significant influence toward entrepreneurship intention. However, this research used different factors to determine student's intention $[5,9,10]$.

This research has purpose to determine perceived behavioral control and subjective norm toward immediate term intention. The research used quantitative method using path analysis and validity and reliability test also. Simple random sampling is used as a sampling method. The sample is 172 students in Private University. This research investigated perceived behavioral control and subjective norm that affect immediate term entrepreneurship intention.

\section{METHOD}

Survey design in this research is a cross-sectional survey design used a questionnaire. The analysis was conducted to college students at Universitas Komputer Indonesia on July 2018. The sample is taken from 172 college students. The college students that is chosen to be respondents in this research are students who have received entrepreneurship education. This could give a reliable answer to this research in knowing students' intention in entrepreneurship.

The questionnaire was adapted from Kim-Soon (2014) which was divided into three parts. The first part discusses about perceived behavioral control. The second part discusses about subjective norm. And the third part discusses about immediate term intention. Likert scale is used to measure perceived behavioral control, subjective norm, and immediate term intention of students in entrepreneurship.

Data analysis method used in this research is path analysis. Validity and reliability test were also used to ensure validity and reliability of data. Validity is the important criteria and indicates the extent to which an instrument to measure what should be measured. Meanwhile 
reliability is a tool that used to measuring instrument to provides consistent results. Path analysis is based on multiple regression analysis that provides relationship between independent and dependent variables [11]. Based on this research, the relationship that will be raised is the relationship between perceived behavioral control and subjctive norm. And also, F-test will be performed to find the effect of perceived behavioral control and subjctive norm toward immediate term intention simultaneously.

The hypothesis proposed in this study are as follows:

H1: Perceived behavioral control has a significant effect on immediate term intention

$\mathrm{H} 2$ : Subjective norm has a significant effect on immediate term intention

H3: Perceived behavioral control and subjective norm have a significant effect on immediate term intention simultaneously

\section{RESULTS AND DISCUSSION}

Before the path analysis is carried out, validity and reliability test are conducted to find out whether the statements in the questionnaire are valid and whether each variable are reliable. Table I below explains the results of validity and reliability test.

TABLE I. THE RESULT OF VALIDITY AND RELIABILITY TEST

\begin{tabular}{|c|c|c|}
\hline Statements & Validity & Reliability \\
\hline PBC1 & 0.619 & \multirow[t]{8}{*}{0.835} \\
\hline PBC2 & 0.666 & \\
\hline PBC3 & 0.676 & \\
\hline PBC4 & 0.662 & \\
\hline PBC5 & 0.700 & \\
\hline PBC6 & 0.734 & \\
\hline PBC7 & 0.685 & \\
\hline PBC8 & 0.727 & \\
\hline SN1 & 0.622 & \multirow[t]{6}{*}{0.626} \\
\hline $\mathrm{SN} 2$ & 0.478 & \\
\hline SN3 & 0.627 & \\
\hline SN4 & 0.656 & \\
\hline SN5 & 0.580 & \\
\hline SN6 & 0.595 & \\
\hline ITI1 & 0.821 & \multirow[t]{6}{*}{0.926} \\
\hline ITI2 & 0.813 & \\
\hline ITI3 & 0.827 & \\
\hline ITI4 & 0.860 & \\
\hline ITI5 & 0.732 & \\
\hline ITI6 & 0.876 & \\
\hline
\end{tabular}

\begin{tabular}{|c|c|c|}
\hline Statements & Validity & \multirow{2}{*}{ Reliability } \\
\hline ITI7 & 0.840 & \\
\cline { 1 - 2 } ITI8 & 0.725 & \\
\hline
\end{tabular}

The results of validity test shows that all statements in the questionnaire have valid values at the significance level of 0.010. Meanwhile, the results of reliability test shows that all variables have Cronbach's Alpha reliability values more than 0.600 .

The next step is to perform data analysis using the path analysis method. This test is conducted to determine whether the research model hypothesis is accepted or rejected. The following is a structural equation of research using the path analysis method:

$$
\begin{aligned}
& \text { ITI }=0.179 * \mathrm{PBC}+1.074 * \mathrm{SN}, \text { Errorvar. }=20.130, \mathrm{R}^{2}=0.435 \\
& \begin{array}{llr}
(0.0902) & (0.129) & (2.190) \\
1.983 & 8.312 & 9.192
\end{array}
\end{aligned}
$$

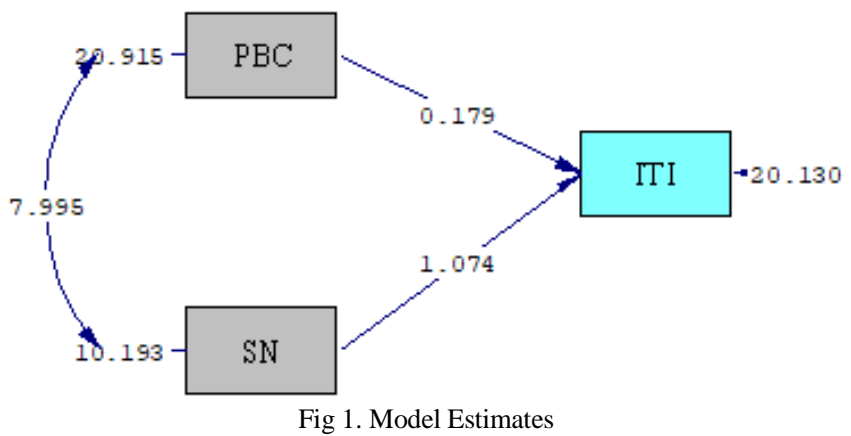

From the results on Figure 1, we can see that estimated value of perceived behavioral control is 0.179 , which means if perceived behavioral control gaining by 1 , it will increase immediate term intention by 0.179 . In the other hand, estimated value of subjective norm is 1.074 , that means if subjective norm gaining by 1 , it will increase immediate term intention by 1.074 .

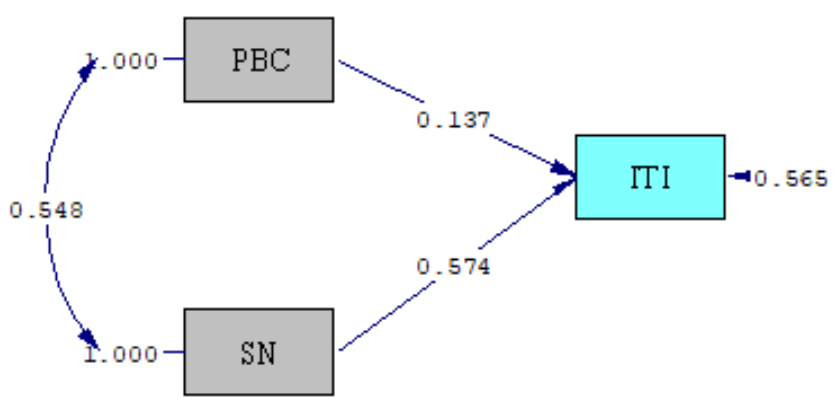

Fig 2. Model Standardized Solution

Standardized solution value on Figure 2 is used to calculate direct and indirect effect of the model. Table II below shows direct and indirect effect of perceived behavioral control and subjective norm toward immediate term intention. 
TABLE II. DIRECT AND INDIRECT EFFECT

\begin{tabular}{|c|c|c|c|}
\cline { 2 - 3 } \multicolumn{1}{c|}{} & \multicolumn{2}{c|}{ Immediate Term Intention } & \multirow{2}{*}{$\begin{array}{c}\text { Total } \\
\text { Effect }\end{array}$} \\
\cline { 2 - 3 } & $\begin{array}{c}\text { Direct } \\
\text { Effect }\end{array}$ & Indirect Effect & Effer \\
\hline $\begin{array}{c}\text { Perceived } \\
\text { Behavioral } \\
\text { Control }\end{array}$ & $\begin{array}{c}0.137^{2} \\
=0.019\end{array}$ & $\begin{array}{c}0.137 \times 0.548 \times 0.574= \\
0.043\end{array}$ & 0.062 \\
\hline $\begin{array}{c}\text { Subjective } \\
\text { Norm }\end{array}$ & $\begin{array}{c}0.574^{2} \\
=0.329\end{array}$ & $\begin{array}{c}0.574 \times 0.548 \times 0.137= \\
0.043\end{array}$ & 0.373 \\
\hline
\end{tabular}

On direct effect, perceived behavioral control contributes $1.9 \%$ to immediate term intention and subjective norm contributes $32.9 \%$. Meanwhile on indirect effect, each of perceived behavioral control and subjective norm contribute $4,3 \%$. Therefore, the total effect of both variables to immediate term entrepreneurship intention is $43.5 \%$ and the rest could be contributed by other factor such as personality traits or contextual factors that is not included in this research.

To answer the research hypothesis, T-test and F-test were conducted to determine whether perceived behavioral control and subjective norms have a significant influence both partially and simultaneously. Figure 3 below explain the influences of perceived behavioral control and subjective norms to immediate term intention.

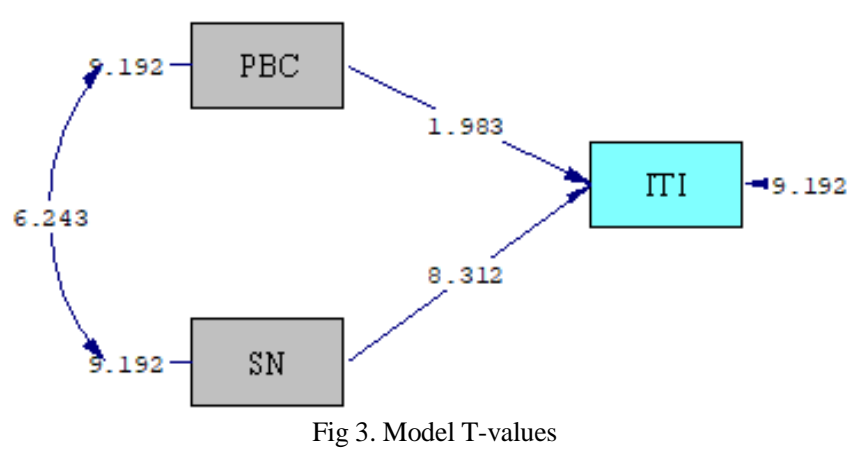

H1 states that there is an effect of perceived behavioral control on immediate term intention. Result is shown in the path diagram with a T-value of 1,983 which has a greater value than T-table of 1,974. This result proves that there is a significant effect of perceived behavioral control on immediate term intention, $\mathrm{H} 1$ is accepted.

Meanwhile, $\mathrm{H} 2$ states that there is an effect of subjective norm on immediate term intention. Result is shown in the path diagram with a T-value of 8,312 which has a greater value than $\mathrm{T}$-table of 1,974 . This result proves that there is a significant effect of subjective norm on immediate term intention, $\mathrm{H} 2$ is accepted.
To determine whether perceived behavioral control and subjective norms simultaneously affect on immediate term intention, statistical F-test is used with the following formula:

$$
F \text { value }=\frac{(n-k-1) R_{x y}^{2}}{k\left(1-R_{x y}^{2}\right.}
$$

$\mathrm{n}$ symbol represents the number of samples in this research, $\mathrm{k}$ symbol represents the number of independent variables, and R2 represents coefficient of determination. The result as follows:

$$
\begin{gathered}
F \text { value }=\frac{(172-2-1) 0,435}{2(1-0,435)}=65,058 \\
F \text { table }(0,05 ; 2 ; 169)=3,049
\end{gathered}
$$

$\mathrm{H} 3$ states that there is an effect of perceived behavioral control and subjective norm on immediate term intention simultaneously. Result is shown above with a F-value of 65,058 which has a greater value than F-table of 3,049. This result proves that there is a significant effect of perceived behavioral control and subjective norm on immediate term intention simultaneously, $\mathrm{H} 3$ is accepted.

The first factor that determine immediate term intention in this research is perceived behavioral control. Perceived behavioral control points to the level of difficulties to performing the behavior based on past experience and anticipated obstacles [6]. It might be affected by skills, resources, and opportunities to performing particular behavior. If someone assumed that they have control over the factors, then they can develop the intention to perform the behavior [8].

The second factor is subjective norm. Subjective norm points to perceived social pressure to perform or not to perform particular behavior [6]. If someone believes that they referents think particular behavior should be performed, then subjective norm will affect they intention to perform that particular behavior. The referents could be a close friends or family [8].

Based on the result, perceived behavioral control and subjective norm affect immediate term intention by $43.5 \%$. This means that both factors can explain the immediate term intention by $43.5 \%$, while the rest is explained by other factors that not included in this research. Other factor that might affect immediate term intention is attitude toward the behavior. This result indicates that the better perceived behavioral control and subjective norm, the higher student's immediate term entrepreneurship intention.

Partially, perceived behavioral control has a significant effect on immediate term intention because T-value (1.983) is greater than T-table (1.974), it can be concluded that perceived behavioral control determines immediate term intention, the better perceived behavioral control, the higher the student's immediate term entrepreneurship intention. And also, subjective norm has a significant effect on immediate term intention because T-value (8.312) is greater 
than T-table (1.974), it can be concluded that subjective norm determines immediate term intention, the better subjective norm, the higher the student's immediate term entrepreneurship intention

As we can see on Table II, subjective norm has more dominant influence on immediate term intention than perceived behavioral control. Subjective norm affects immediate term intention by $37.3 \%$ and perceived behavioral control only affect immediate term intention by $6.2 \%$. This result shows that the intention to behave as a successful entrepreneur is dominantly influenced by the existence of subjective norms of important referents. It can support and motivates someone to become a successful entrepreneur. This research proves that perceived behavioral controls and subjective norms are important factors that influence student's intention to become an entrepreneur. Motivations may contribute in explaining how entrepreneurial intention is formed. Different motivations can lead to different levels of perceived behavioral control and subjective norm to determine entrepreneurship intentions [3].

Due to limited conditions, we only perform the partial model of Ajzen's Theory of Planned Behavior. This research only focusing on perceived behavioral control and subjective norm and its impact on immediate term intention. Further research is needed to complement this research by adding another factor that may affect entrepreneurship intention.

\section{CONCLUSION}

The result of this research indicated that perceived behavioral control and subjective norm have significant effect on immediate term entrepreneurship intention either partially or simultaneously. The finding of the result contributes the references to encourage the students in managing entrepreneurial intention, which in turn creating new entrepreneur. Further research on other factor in Ajzen's Theory of Planned Behavior need to be conducted.

\section{ACKNOWLEDGMENT}

This research supported by Universitas Komputer Indonesia. We wish to thank the students who have responded to the survey questionnaire for their time and patience for participating in this research.

\section{REFERENCES}

[1] Lee, Sang M., Daesung Chang, and Seong-Bae Lim. "Impact of entrepreneurship education: A comparative study of the US and Korea." The International Entrepreneurship and Management Journal 1.1 (2005): 27-43.

[2] Ghina, Astri. "Effectiveness of entrepreneurship education in higher education institutions." Procedia-Social and Behavioral Sciences 115 (2014): 332-345

[3] Solesvik, Marina Z. "Entrepreneurial motivations and intentions: investigating the role of education major." Education+ Training 55.3 (2013): 253-271.

[4] Ryan, Richard M., and Edward L. Deci. "Self-determination theory and the facilitation of intrinsic motivation, social development, and well-being." American psychologist 55.1 (2000): 68.

[5] Obschonka, Martin, Rainer K. Silbereisen, and Eva SchmittRodermund. "Entrepreneurial intention as developmental outcome." Journal of Vocational Behavior 77.1 (2010): 63-72.
[6] Ajzen, Icek. "Attitudes, traits, and actions: Dispositional prediction of behavior in personality and social psychology." Advances in experimental social psychology. Vol. 20. Academic Press, 1987. 1-63.

[7] Kim-Soon, $\mathrm{Ng}$, Abdul Rahman Ahmad, and Nurul Nadia Ibrahim. "Entrepreneurial motivation and entrepreneurship career intention: Case at a Malaysian Public University." Crafting Global Competitive Economies 2020 (2014): 1001-1011.

[8] Ariff, Mohd, et al. "Predicting Entrepreneurship Intention Among Malay University Accounting Students in Malaysia." UNITAR e-Journal 6.1 (2010).

[9] Lüthje, Christian, and Nikolaus Franke. "The 'making'of an entrepreneur: testing a model of entrepreneurial intent among engineering students at MIT." R\&d Management 33.2 (2003): 135-147.

[10] Krueger Jr, Norris F., Michael D. Reilly, and Alan L. Carsrud. "Competing models of entrepreneurial intentions." Journal of business venturing 15.5-6, pp. 411-432, 2000.

[11] Kothari, Chakravanti Rajagopalachari. Research methodology: Methods and techniques. New Age International, 2004. 